\title{
Phenotypic and genotypic studies on Escherichia coli strains isolated from food products of animal origin
}

\author{
Khafagy, A., A.;EL Shourbagy, M., A*;Hanaa, M., F. ${ }^{* *}$ and Samah, K. A.**** \\ Bacteriology, Immunology and Mycology department- Faculty of Veterinary \\ Medicine-Suez Canal University; * Anaerobics unit, animal health research \\ institute, Dokki, Giza; ** Department of animal hygiene, zoonosis \& animal \\ behavior-Faculty of Veterinary Medicine-Suez Canal University and *** \\ Faculty of Veterinary Medicine-Suez Canal University
}

\begin{abstract}
Foodstuffs of animal origin may present hazards, due to bacterial contamination. This study was conducted to determine Escherichia coli in some types of animal source foods (raw milk, raw beef meat and raw poultry meat). Bacteriological examination of total 246 raw food samples of animal origin, raw milk, (105); beef meat (31) and poultry meat (110) were collected from different localities in Ismailia City showed that 64/246 (26.01\%) of samples were infected with E. coli. Serological identification of (10) E. coli strains revealed that they were belonged to $\mathbf{O}_{111}$ polyvalent $1 ; \mathbf{O}_{44}$ polyvalent 2 ( 2 strains for each); $\mathbf{O}_{78}$ polyvalent $4 ; \mathbf{O}_{146}$ polyvalent 2 ; $\mathbf{O}_{26}$ polyvalent $1 ; \mathbf{O}_{119}$ polyvalent $1 ; \mathbf{O}_{86}$ polyvalent 1 and $\mathbf{O}_{18}$ polyvalent 3 (1 strain for each). E. coli strains showed high susceptible rate to Ciprofloxacin (CIP), (100\%) and high resistance $(100 \%)$ to Ampicillin (AMP), Metronidazole (MTZ), Amoxicillin (AML), and Vancomycin (VAS). Four strains of the isolated E. coli were submitted to molecular studies for detection of the eaeA (protein intimin), iutA (encoding aerobactin) and iss (increased serum survival protein) genes, by using PCR technique.
\end{abstract}

\section{Introduction}

Foods and microorganisms have long and interesting association which developed longer before the beginning of recorded history (Dilbaghi and Sharma, 2007). Since its discovery in 1805, E. coli was considered a harmless, Gramnegative, motile, non-sporulating; rod shaped, facultative anaerobic bacterium and is one of the main inhabitants of the intestinal tract of most mammalian species, including humans and birds. As it is present in high number in intestine, E. coli are often used as marker organisms. Detecting and counting of E. coli is used as a reliable indicator of fecal contamination and indicates a possible presence of enteropathogenic and/or toxigenic microorganisms in foods and water 
which constitute a public health hazard (Kaper et al, 2004 and Dilbaghi and Sharma, 2007). Pathogenic E. coli are classified into categories based on the production of virulence factors and on the clinical manifestations that they cause. In addition to the presence of E.coli denoting fecal pollution, the presence of virulencerelated genes in E. coli strains refers to the pathogenicity of the isolates (Klie et al, 1997; Jayarao and Henning, 2001 and Holko et al, 2006). The protein intimin (encoded by the chromosomal gene eae), is responsible for the intimate attachment of the bacteria to intestinal epithelial cells (Law, 2000 and Gyles, 2007). iutA encoding aerobactin system is one of serum survival genes, that are specific virulence markers associated with extraintestinal infection. The explanation of their occurrence could be the possibility of udder infection (Altalhi and Hassan, 2009). Isolates with the aerobactin system have a growth advantage in low-iron conditions (Montgomerie et al, 1984) and, in comparison to the other major specialized siderophore, enterobactin, aerobactin is more effective.

Considering the above mentioned data, the present study thus was planned to assess the bacteriological quality of some types of animal source foods by investigating Escherichia coli, which may contaminate them, through the following topics:
1- Collection of raw milk, raw beef meat and raw poultry meat samples from different localities in Ismailia City.

2- Isolation of suspected Escherichia coli isolates which may be found in them.

3- Biochemical identification of the isolated Escherichia coli.

4- Serological identification of some isolated Escherichia coli strains.

5- Antibiogram study of the isolated Escherichia coli strains.

6- Detection of the eaeA (protein intimin), iutA (encoding aerobactin) and iss (increased serum survival protein) gene factors that may be expressed in the examined Escherichia coli serovars.

\section{Material and methods:}

\section{1- Isolation and identification of E.coli strains:}

Escherichai coli were isolated from a total number of 246 raw food samples of animal origin, (105) raw milk samples, (31) beef meat samples and (110) poultry meat samples, by cultivation into $1 \%$ peptone water as pre-enrichment media, Brilliant Green Bile 2\% broth as enrichment media, then on MacConkey's agar and by subcultivation on Sorbitol MacConkey's agar, sheep blood agar and Eosin methylene blue agar (EMB) and wrer identified by biochemical tests. Ten E. coli isolates were serologically identified by using slide agglutination test. Antibiotic 
susceptibility of the isolated $E$. coli was performed, using standard plate technique as recommended by Clinical laboratory Standard Institute (CLSI). Four strains of the serologically identified E. coli were submitted to molecular studies for detection of the eaeA (protein intimin), iutA (encoding aerobactin) and iss (increased serum survival protein) genes by using PCR technique.

2-Molecular studies on $\boldsymbol{E}$. coli strain

\section{2-1- Extraction of DNA,} according to QIAamp DNA mini kit instructions

1- $20 \mu \mathrm{l}$ QIAGEN protease were pipetted into the bottom of a $1.5 \mathrm{ml}$ micro centrifuge tube, $200 \mu \mathrm{l}$ of the bacterial broth culture and $200 \mu 1$ buffer AL were added to the sample, then mixed by pulse vortexing for 15 seconds, then the mixture was incubated at $56^{\circ} \mathrm{C}$ for $10 \mathrm{~min}$. After incubation, the $1.5 \mathrm{ml}$ micro centrifuge tubes were centrifugated to remove drops from the inside of the lid.

2- $200 \mu \mathrm{l}$ ethanol (96\%) were added to the sample, and mixed again by pulse vortexing for 15 seconds. After mixing, the $1.5 \mathrm{ml}$ micro centrifuge tube was briefly centrifugated to remove drops from the inside of the lid.

3- The mixture from step 2 was carefully applied to the QIAamp mini spin column (in a $2 \mathrm{ml}$ collecting tube) without wetting the rim. The cap was closed, and centrifugated at $8000 \mathrm{rpm}$ for $1 \mathrm{~min}$.
The QIAamp mini spin column was placed in a clean $2 \mathrm{ml}$ collection tube, and the tube containing the filtrate was discarded.

4- The QIAamp mini spin column was carefully opened and $500 \mathrm{ml}$ buffer AW1was added without wetting the rim. The cap was closed, and centrifugated at 8000 rpm for $1 \mathrm{~min}$. The QIAamp mini spin column was placed in a clean 2 $\mathrm{ml}$ collection tube, and the tube containing the filtrate was discarded.

5- The QIAamp mini spin column was carefully opened and $500 \mathrm{ml}$ buffer AW2 were added without wetting the rim. The cap was closed, and centrifugated at full speed for 3 minutes.

6- The QIAamp mini spin column was placed in a new $2 \mathrm{ml}$ collection tube and the old collection tube was discarded with the filtrate. Centrifugation at full speed for 1 min was done.

7- The QIAamp mini spin column was placed in a clean $1.5 \mathrm{ml}$ micro centrifuge tube, and the collection tube containing the filtrate was discarded. The QIAamp mini spin column was carefully opened and $100 \mu \mathrm{l}$ buffer AE were added. The QIAamp mini spin column was incubated at room temperature (15$25^{\circ} \mathrm{C}$ ) for 1 minute, and then centrifugated at $8000 \mathrm{rpm}$ for 1 minute.

2-2-Oligonucleotide primers sequences of $E$. coli genes:

2-3- Cycling conditions of the different primers during PCR of 
the tested $E$. coli genes according to specific authors and Emerald Amp GT PCR mastermix (Takara) kit.

2-4- DNA Molecular weight marker

The ladder (Gel Pilot 100 bp ladder (cat. no. 239035), supplied from QIAGEN (USA). Number of bands: 6, Size range: 100-600 bp.)was mixed gently by pipetting up and down. $6 \mu \mathrm{l}$ of the required ladder were directly loaded.

2-5- Agarose gel electrophoresis according to Sambrook et al, 1989, with modification

Electrophoresis grade agarose $(2 \mathrm{~g})$ was prepared in $100 \mathrm{ml}$ TBE buffer in a sterile flask, it was heated in microwave to dissolve all granules with agitation, and allowed to cool at $70^{\circ} \mathrm{C}$, then $0.5 \mu \mathrm{g} / \mathrm{ml}$ ethedium bromide was added and mixed thoroughly.

The warm agarose was poured directly in gel casting apparatus with desired comb in apposition and left at room temperature for polymerization.

The comb was then removed, and the electrophoresis tank was filled with TBE buffer. Ten to fifteen $\mu 1$ of each PCR product samples, negative control and positive control were loaded to the gel. The power supply was $1-5$ volts $/ \mathrm{cm}$ of the tank length. The run was stopped after about $30 \mathrm{~min}$ and the gel was transferred to UV cabinet.

The gel was photographed by a gel documentation system and the data was analyzed through computer software.

Table (1): Oligonucleotide primers sequences of E. coli genes:

\begin{tabular}{|c|c|c|c|}
\hline $\begin{array}{l}\text { Prime } \\
\mathbf{r}\end{array}$ & Sequence & $\begin{array}{c}\text { Amplifie } \\
\text { d } \\
\text { product }\end{array}$ & $\begin{array}{l}\text { Reference } \\
\text { s }\end{array}$ \\
\hline \multirow{2}{*}{$e a e A$} & $\begin{array}{c}\text { Forward/ } \\
\text { GACCCGGCACAAGCATAAGC }\end{array}$ & \multirow{2}{*}{$384 \mathrm{bp}$} & \multirow{2}{*}{$\begin{array}{c}\text { Wen-jie } \\
\text { JIN et al., } \\
2008\end{array}$} \\
\hline & $\begin{array}{c}\text { Reverse/ } \\
\text { CCACCTGCAGCAACAAGAGG }\end{array}$ & & \\
\hline \multirow[t]{2}{*}{ Iss } & $\begin{array}{c}\text { Forward/ } \\
\text { ATGTTATTTTCTGCCGCTCTG }\end{array}$ & \multirow[t]{2}{*}{$266 \mathrm{bp}$} & \multirow{4}{*}{$\begin{array}{c}\text { Yaguchi } \\
\text { et al., } \\
2007\end{array}$} \\
\hline & Reverse/CTATTGTGAGCAATATACCC & & \\
\hline \multirow{2}{*}{$i u t A$} & $\begin{array}{c}\text { Forward/ } \\
\text { GGCTGGACATGGGAACTGG }\end{array}$ & \multirow{2}{*}{$300 \mathrm{bp}$} & \\
\hline & $\begin{array}{c}\text { Reverse/CGTCGGGAACGGGTAGAAT } \\
\text { CG }\end{array}$ & & \\
\hline
\end{tabular}


Table (2) Cycling conditions of the different primers of the E. coli genes

\begin{tabular}{|l|c|c|c|c|c|c|}
\hline Genes & $\begin{array}{l}\text { Primary } \\
\text { denaturation }\end{array}$ & $\begin{array}{l}\text { Secondary } \\
\text { denaturation }\end{array}$ & Annealing & Extension & $\begin{array}{l}\text { No. of } \\
\text { cycles }\end{array}$ & $\begin{array}{l}\text { Final } \\
\text { extension }\end{array}$ \\
\hline eaeA & $\begin{array}{c}94^{\circ} \mathrm{C} \\
5 \mathrm{~min} .\end{array}$ & $\begin{array}{c}94^{\circ} \mathrm{C} \\
45 \mathrm{sec} .\end{array}$ & $\begin{array}{c}54^{\circ} \mathrm{C} \\
45 \mathrm{sec} .\end{array}$ & $\begin{array}{c}72^{\circ} \mathrm{C} \\
45 \mathrm{sec} .\end{array}$ & 35 & $\begin{array}{c}72^{\circ} \mathrm{C} \\
10 \mathrm{~min} .\end{array}$ \\
\hline Iss & $\begin{array}{c}94^{\circ} \mathrm{C} \\
5 \mathrm{~min} .\end{array}$ & $\begin{array}{c}94^{\circ} \mathrm{C} \\
30 \mathrm{sec} .\end{array}$ & $\begin{array}{c}54^{\circ} \mathrm{C} \\
30 \mathrm{sec} .\end{array}$ & $\begin{array}{c}72^{\circ} \mathrm{C} \\
30 \mathrm{sec} .\end{array}$ & 35 & $\begin{array}{c}72^{\circ} \mathrm{C} \\
10 \mathrm{~min} .\end{array}$ \\
\hline iutA & $\begin{array}{c}94^{\circ} \mathrm{C} \\
5 \mathrm{~min} .\end{array}$ & $\begin{array}{c}94^{\circ} \mathrm{C} \\
30 \mathrm{sec} .\end{array}$ & $\begin{array}{c}63^{\circ} \mathrm{C} \\
30 \mathrm{sec} .\end{array}$ & $\begin{array}{c}72^{\circ} \mathrm{C} \\
30 \mathrm{sec} .\end{array}$ & 35 & $\begin{array}{c}72^{\circ} \mathrm{C} \\
10 \mathrm{~min} .\end{array}$ \\
\hline
\end{tabular}

\section{Results:}

*Biochemical examination revealed identification of $64 E$. coli strains at percentage of $26.01 \%$ of the examined samples (27 strains, at percentage of $25.71 \%$ of the examined milk samples, 8 strains, at percentage of $25.80 \%$ of the examined beef meat samples and 29 strains, at percentage of $26.36 \%$ of the examined poultry meat samples).

*Serological identification of (10) $E$. coli isolated from the examined samples revealed that they were belonged to $\mathbf{O}_{111}$ polyvalent $1 ; \mathbf{O}_{44}$ polyvalent 2 (2 strains for each); $O_{78}$ polyvalent 4; $O_{146}$ polyvalent $2 ; \mathbf{O}_{26}$ polyvalent $1 ; \quad \mathbf{O}_{119}$ polyvalent 1; $\mathbf{O}_{86}$ polyvalent 1 and $\mathbf{O}_{18}$ polyvalent 3 (1 strain for each). *The antimicrobial sensitivity of the isolated E. coli showed high susceptible rate to Ciprofloxacin (CIP), (100\%), followed by Cefoperazone (CFP), (75\%); Enrofloxacin (ENR), (73.44\%); Cefotaxime (CTX), (70.31\%);
Streptomycin (S), (48.44\%) and Colistin sulphate (CT), (45.31\%). On the other hand, all strains (100\%) were resistant to Ampicillin (AMP), Metronidazole (MTZ), Amoxicillin (AML) and Vancomycin (VAS).

*The molecular studied resulted in: - The protein intimin (encoded by eae gene) was found in $E$. coli serovars ; $\mathbf{O}_{18}$ polyvalent $3 ; \mathbf{O}_{111}$ polyvalent 1 and $\mathbf{O}_{44}$ polyvalent 2 , with a size of 384 base pairs, while the examined gene was not found in $E$. coli serovar, $O_{146}$ polyvalent 2.

- The aerobactin iutA gene was present in the four examined E. coli serovars , $\left(\mathrm{O}_{18}\right.$ polyvalent $3 ; \mathbf{O}_{111}$ polyvalent $1 ; \mathbf{O}_{44}$ polyvalent 2 , and $\mathbf{O}_{146}$ polyvalent 2 ), with a size of 300 base pairs.

- coli, $\mathbf{O}_{146}$ polyvalent 2 , did not have the increased serum survival iss gene, while the other 3 serovars $\left(O_{18}\right.$ polyvalent $3 ; O_{111}$ polyvalent 1 and $\mathrm{O}_{44}$ polyvalent 2 ) had it, with a size of 266 base pairs. 
Table (3): Results of biochemical identification and frequency of distrebution of E. coli among the examined food samples

\begin{tabular}{|c|c|c|c|}
\hline Types of samples & No. of samples & No. of isolated $\boldsymbol{E}$. coli & \% \\
\hline Raw milk & 105 & 27 & 25.71 \\
\hline Raw beef meat & 31 & 8 & 25.80 \\
\hline Raw Poultry meat & 110 & 29 & 26.36 \\
\hline Total & 246 & 64 & 26.01 \\
\hline
\end{tabular}

Table (4) Results of serological identification of the examined E. coli strains (10 strains)

\begin{tabular}{|c|c|c|}
\hline Monovalent & Polyvalent & No. \\
\hline $\mathbf{O}_{111}$ & polyvalent 1 & 2 strains \\
\hline $\mathrm{O}_{44}$ & polyvalent 2 & 2 strains \\
\hline $\mathrm{O}_{78}$ & polyvalent 4 & 1 strain \\
\hline $\mathrm{O}_{146}$ & polyvalent 2 & 1 strain \\
\hline $\mathrm{O}_{26}$ & polyvalent 1 & 1 strain \\
\hline $\mathrm{O}_{119}$ & polyvalent 1 & 1 strain \\
\hline $\mathrm{O}_{86}$ & Polyvalent 1 & 1 strain \\
\hline $\mathrm{O}_{18}$ & polyvalent 3 & 1 strain \\
\hline \multicolumn{2}{|c}{} \\
\hline
\end{tabular}

Table (5) Antimicrobial sensitivity test of the isolated Escherichia coli serovars from the examined samples

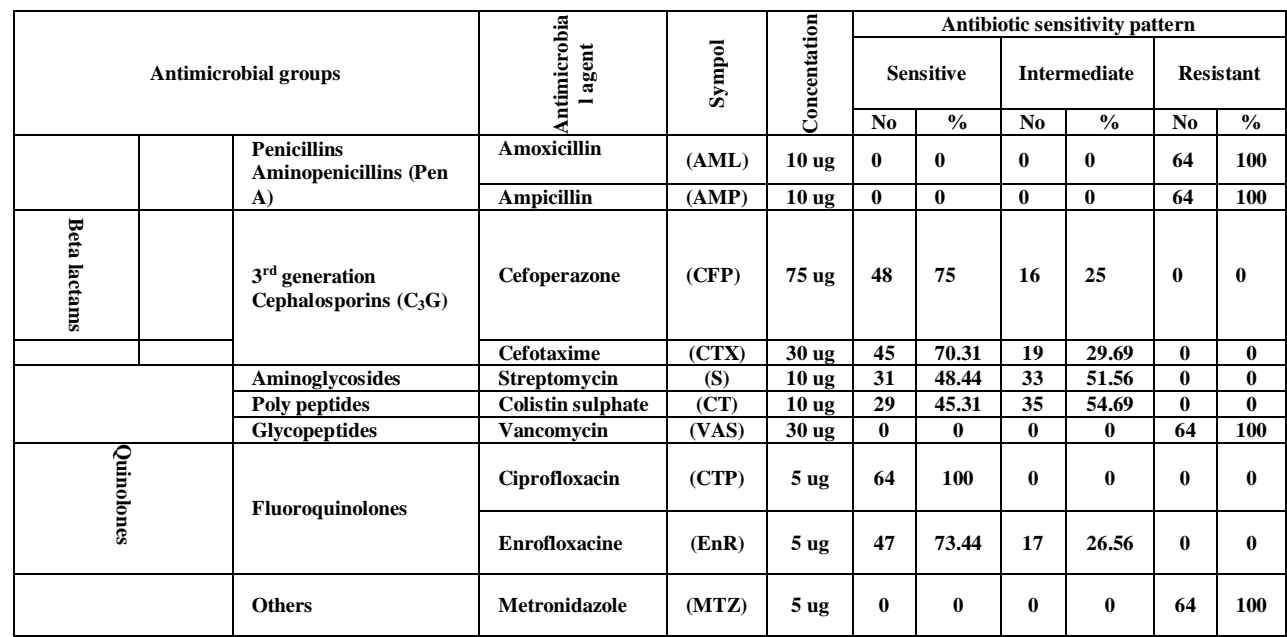




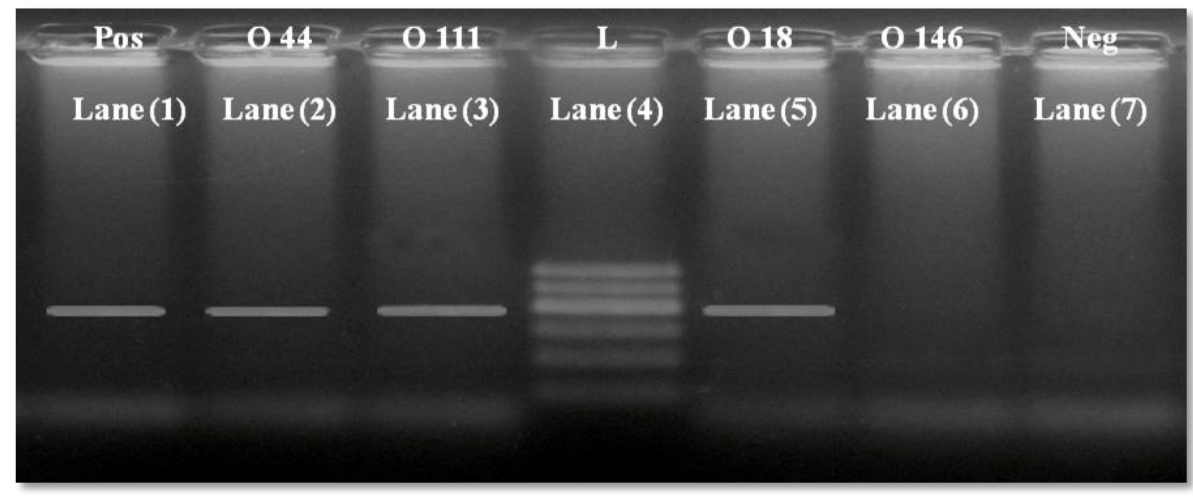

Figure (1) Agarose gel electrophoresis of amplified eaeA gene PCR product (384bp)

Lane1: Positive control for eaeA gene.

Lane 2,3 \&:5 : Positive strains for eaeA gene (384 bp).

Lane 4: One step ladder (600bp).

Lane 6: Negative strains for eaeA gene.

Lane7: Negative control.

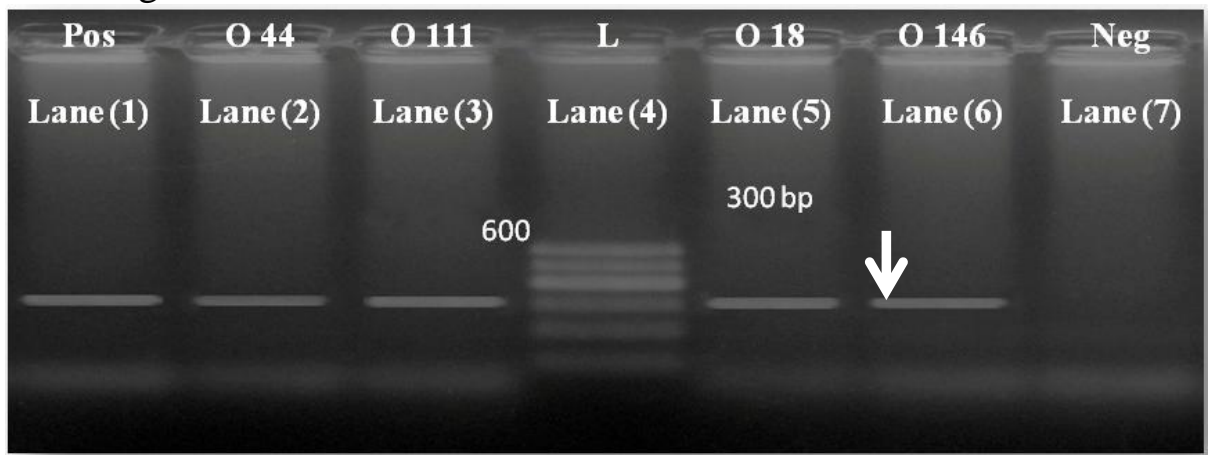

Figure (2) Agarose gel electrophoresis of amplified iutA gene PCR product (300 bp)

Lane1: Positive control for iutA gene.

Lane $2,3,5$ and 6 : Positive strains for iutA gene (300 bp)

Lane 4: 100 bp ladder (100-600bp).

Lane7: Negative control for iutA gene. 


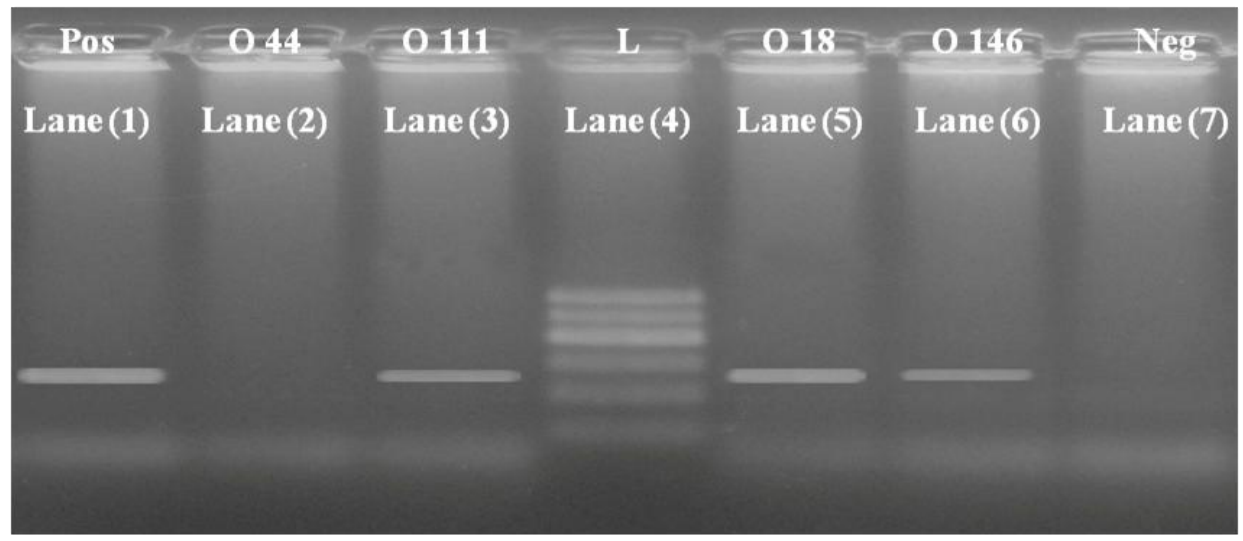

Figure (3) Agarose gel electrophoresis of amplified iss gene PCR product (266 bp)

Lane1: Positive control for iss gene.

Lane2: Negative strain for iss gene.

Lane 3, 5 and 6 : Positive strains for iss gene (266 bp)

Lane 4:100 bp ladder (100-600bp).

Lane7: Negative control

\section{Discussion}

Out of 105 raw milk samples, Escherichia coli could be detected in 27 samples, comprising $25.71 \%$ of the examined raw milk samples. Corresponding results were obtained by El-Jendy, (2004), who isolated $\boldsymbol{E}$. $24 \%$ of the examined samples. Higher values were reported by Abd-Allah (2002), $(66 \%)$ from raw market samples \& $(86 \%)$ from raw bulk milk samples. Sudershan \& Ashwani (1996), recovered E. coli at lower level $(10.19 \%)$ of 108 raw milk samples, collected from Hisar, India.

The presumed route of $\boldsymbol{E}$. coli contamination of raw milk is via fecal contamination during milking (Hussein \& Sakuma, 2005). However, direct excretion of the organisms from the infected udder has also been reported (Lira et al.,
2004). Moreover, E. coli is regarded as an indicator of poor hygiene and sanitary practices during milking and further handling, (Altalhi \& Hassan, 2009).

For the examined raw meat samples, 8 isolates of Escherichia coli, at percentage of $(25.80 \%)$ of the examined samples. Nearly similar result was given by Mona (2002), (24\%). Higher values were obtained by Elwi (1994), (93.3\%). Lowe records were given Neveen (2002), (10\%). Opposite result was stated by Khalafalla (1996), who determined 30 samples of raw meats (10 each of brisket meat, chuck meat and cubes from hind quarter) and $\boldsymbol{E} . \boldsymbol{c o l i}$ were failed to be detected from any of the examined samples. 
E.coli and Salmonella species are two of bacterial genera that commonly infect meat while it is being processed, cut, packaged, transported, sold and handled. These organisms spoiling meat may infect the animal either while it is live "endogenous disease" or may contaminate the meat after its slaughter "exogenous disease" (Lawrie \& Ledward, 2006).

Twenty nine isolates of Escherichia coli were obtained from the examined raw poultry meat samples, at percentage of $29.59 \%$ of the examined samples. Corresponding results were mentioned by Mona (2002), (30\%) Higher values were shown by Rofiel (1999), (40\%); Lower result was given by Ghada (1997), (20\%). Serological identification of (10) representative $E$. coli strains, isolated from the examined samples, raw milk, raw beef meat and raw poultry meat, revealed that they were belonged to $\mathrm{O}_{111}$ polyvalent $1, \mathrm{O}_{44}$ polyvalent 2 ( 2 strains for each), $\mathrm{O}_{78}$ polyvalent 4 , $\mathrm{O}_{146}$ polyvalent $2, \mathrm{O}_{26}$ polyvalent 1 , $\mathrm{O}_{119}$ polyvalent $1, \mathrm{O}_{86}$ polyvalent 1 and $\mathrm{O}_{18}$ polyvalent 3 ( 1 strain for each). Noha (2008) isolated Escherichia coli from slaughtered and apparently healthy chicken, which serologically identified as $\mathrm{O}_{78}, \mathrm{O}_{1}, \mathrm{O}_{2}, \mathrm{O}_{8}, \mathrm{O}_{27} \mathrm{O}_{119}, \mathrm{O}_{126}, \mathrm{O}_{125}$, $\mathrm{O}_{26}, \mathrm{O}_{87}, \mathrm{O}_{128}$ and $\mathrm{O}_{146}$.

Enteropathogenic Escherichia coli (EPEC) traditionally has been reserved for the classic serovars: $\mathrm{O}_{26}, \mathrm{O}_{86}, \mathrm{O}_{111}, \mathrm{O}_{114}, \mathrm{O}_{119}, \mathrm{O}_{125}$,
$\mathrm{O}_{128}, \mathrm{O}_{142}$ and $\mathrm{O}_{158}$ and are a special group organisms associated with out-breaks of children diarrhea (Wolfang et al, 1992).

All strains (100\%) showed resistance to Ampicillin (AMP), Amoxicillin (AML), (both are related to Beta lactams, Aminopenicillins); Vancomycin (VAS), (Glycopeptides) and Metronidazole (MTZ).

Some of this bacterial resistance related with $\mathrm{R}$-factor that lead to trance multiple resistance of antibiotic at some time and that happens mostly in bacteria that cause diarrhea (Smith et al, 1973; Ryder et al, 1980 and Sur et al, 2003).

The protein intimin (encoded by eae gene) was expressed in E. coli serovars; $\mathrm{O}_{18}$ polyvalent $3 ; \mathrm{O}_{111}$ polyvalent 1 and $\mathrm{O}_{44}$ polyvalent 2 , with a size of 384 base pairs, while the examined gene was not expressed in E. coli serovar $\mathrm{O}_{146}$ polyvalent 2. Jelacic et al (2003) analyzed, by polymerase chain reaction, 82 Shiga toxin-producing Escherichia coli (STEC) isolates and found that all E. coli $\mathrm{O} 157: \mathrm{H} 7$ contained eae.

The aerobactin iutA gene was expressed in the four examined $E$. coli serovars, $\left(\mathrm{O}_{18}\right.$ polyvalent 3 ; $\mathrm{O}_{111}$ polyvalent $1 ; \mathrm{O}_{44}$ polyvalent 2 , and $\mathrm{O}_{146}$ polyvalent 2 ), with a size of 300 base pairs. Altalhi and Hassan (2009) screened E. coli strains, isolated from raw milk sources, for markers of extraintestinal pathogenic E. coli 
(ExPEC) using PCR assays and suggested that iutA (11 strains) was one of the most frequent virulence markers. Systems to meet the bacterial need for iron during infection is one of factors that are probably important for the establishment of

Enterohaemorrhagic Escherichia coli (EHEC) in the gut and add to the bacterial virulence (WelinderOlsson and Kaijser, 2005).

E. coli $\mathrm{O}_{146}$ polyvalent 2, did not react the increased serum survival gene iss positively with iss gene, while the other 3 serovars $\left(\mathrm{O}_{18}\right.$ polyvalent $3 ; \mathrm{O}_{111}$ polyvalent 1 and $\mathrm{O}_{44}$ polyvalent 2 ) expressed it, with a size of 266 base pairs. examined the prevalence of the three iss types among $487 \mathrm{E}$. coli isolates and found that the iss type 3 geneS was found to occur at a high frequency among extraintestinal pathogenic Escherichia coli (ExPEC) isolates, irrespective of the host source and reported that the increased serum survival gene iss has long been recognized for its role in extraintestinal pathogenic Escherichia coli (ExPEC) virulence.

The findings of this study revealed that some raw foods of animal origin sold to the public in some areas in Ismailia City were contaminated with E.coli. The possible sources of these contaminants are due to the unhygienic manner of handling .This implies that these foods are viable source of various diseases.
Some of these diseases could spread and acquire epidemic status which poses serious health hazards. It is believed that cooking processes and hygiene could greatly reduce the microbial load to harmless level (Agnes, 1995).

\section{References}

Abd-Allah, M.I.M.I. (2002): Hygienic quality of concentrated and raw milks sold in Damietta Governorate. Ph. D. of Vet. Med. Sci. thesis (Hygiene of milk, milk products, fats \& oils and eggs). Department of Food Control, Faculty of Veterinary Medicine, Zagazig University, Egypt.

Agnes, C.H. (1995): Food Microbial Journal 16:226-280.

Altalhi, D. A. and Hassan A. S. (2009): Bacterial quality of raw milk investigated by Escherichia coli and isolates analysis for specific virulence-gene markers Food Control; 20: 913-917.

Dilbaghi, N. and Sharma, S. (2007): Food and industrial microbiology. "Food spoilage, food infections and intoxications caused by microorganisms and methods for their detection". Introduction, P. (1$3)$.

El. Jendy, I.M.S.I.A. (2004): Studies on Enterobacteriaceae in milk and some dairy products. M. vet. Med. Sci. thesis (Hygiene of Milk, Milk products, fat \& oils and eggs). Department of Food Control, Zagazig University, Egypt.

Elwi, E.M. (1994): Sanitary improvement of meat meals in governmental hospitals in Assiut 
City. Ph. D. Vet. Sci. thesis (Meat hygiene), Department of food control, Faculty of veterinary medicine, Assiut University, Egypt.

Ghada, M.I. (1997): Microbiological and sensory evaluation of fresh broiler chicken carcass. M. Vet. Sci. thesis (Meat hygiene), Department of food hygiene, Faculty of veterinary medicine, Alex. University, Egypt.

Gyles, C.L. (2007): Shiga toxinproducing Escherichia coli: an overview. Journal of Anim Science; 85: E45-62.

Holko, I.; Bisova, T.; Holkova, Z. and Kmet, V. (2006): Virulence markers of Escherichia coli strains isolated from traditional cheeses made from unpasteurised sheep milk in Slovakia. Food Control, 17, 393-396. Wochenschrift; 110: 337341.

Hussein, H.S. and Sakuma, T. (2005): Prevalence of shiga toxinproducing Escherichia coli in dairy cattle and their products. Journal of Dairy Science; 88: 450-65.

Jayarao, B.M. and Henning, D.R. (2001): Prevalence of food borne pathogens in bulk tank milk. Journal of Dairy Science, 84(10): 2157- 2162.

Jelacic, K.J.; Damrow, T. ; Chen, G.S.; Jelacic, S.; Bielaszewska, M.; Ciol, M., Carvalho, H.M.; Melton-Celsa, A. R.; O'Brien, A.D. and Tarr, P.I. (2003): Shiga Toxin-Producing Escherichia coli in Montana: Bacterial Genotypes and Clinical Profiles. J Infect Dis.; 188 (5): 719-729.
Kaper, J. B., Nataro, J. P., and Mobley, H. L.T (2004): Pathogenic Escherichia coli. Natural Reviews Microbiology; 2: 123-40.

Khalafalla, F.A. (1996): Microbial evaluation of raw meats, meat products and non-meat ingredients. Beni-Suef Vet. Med. Res. VI, 2: 141.

Klie, H.; Timm, M.; Richter, H.; Gallien, P.; Perlberg, K.W. and Steinruck, H. (1997): Detection and occurrence of verotoxinforming and/or Shigatoxin producing Escherichia coli (VTEC and/or STEC) in milk. Berliner und Munchener Tierarztliche Wochenschrift; 110: 337-341.

Law, D. (2000): Virulence factors of Escherichia coli $\mathbf{O}_{157}$ and other Shiga toxin-producing E. coli. Journal of Applied Microbiology; 88:729-45. Lawrie, R.A. \& Ledward, D.A. (2006): The Preservation Effect of smoke on Meat. Meat science. Cambridge, Woodhead Publication.

Lira, W.M.; Macedo, C. and Marin, J.M. (2004): The incidence of Shiga toxin-producing Escherichia coli in cattle with mastitis in Brazil. Journal of Applied Microbiology; 97: 861-6.

Mona, M.I. (2002): Bacteriological studies on food poisoning microorganisms present in hospitals food of animal origin and their handlers. Ph.D.Vet. Sci. thesis (Bacteriology, Immunology \& Mycology), Faculty of veterinary medicine, Suez Canal University, Egypt. 
Montgomerie, J.Z.; Bindereif, A.; Neilands, J.B.; Kalmanson, G.M. and Guze, L.B. (1984): Association of hydroxamate siderophore (aerobactin) with Escherichia coli isolated from patients with bacteraemia. Infect Immun; 46: 835_8.

Neveen, H.E.A. (2002):

Microbiological investigations of meat serving establishments . Ph. D. Vet. Med. Sci. thesis (Meat, fish \& poultry Hygiene), Departement of food control, Faculty of veterinary medicine, zagazig University, Egypt.

Noha, A.H. (1995): Samonellae in meat and poultry meat products using immune fluorescent technique. M. Vet. Sci. thesis (Meat hygiene), Faculty of veterinary medicine, Cairo University, Egypt.

Rofiel, B.Y. (1999): Aspects on organoleptic and microbiological changes of frozen poultry. M. Vet. Med. Sci. thesis (Meat Hygiene), Faculty of veterinary medicine, Zagazig University, Egypt.

Ryder, R.W.; Blake, P.A.; Murlin, A.C.; Carter, G.P.; Pollard,R.A.; $\quad$ Merson,N.H.; Allen, S.D. and Brenner, D.J. (1980): Increase in antibiotic resistance among isolates of Salmonella in United States, Journal of Infectious Diseases; 142(4): 485490.

Sambrook, J.; Fritsch, E.F. and Maniatis, T. (1989): Molecular coloning: A laboratory manual, Vol $1, \quad 2^{\text {nd }}$ Edition. Cold spring
HarborLaboratotry press, New York.

Smith, H.R.; Grindly, N.D.; Hampheryes, G.O. and Anderson, K.O. (1973): Salmonella and Campylobacter. J. Bact. 115:623.

Sudershan, K. and Ashwani, K. (1996): Occurrence of some bacterial pathogens of public health significance in bovine raw milk. Haryana Vetrinarian; 35; 31-34. Dairy Science Abst.; 60(4):281,(1998) .

Sur, D.; Niyogi, S.; Sur, S.; Tackeda, Y. and Nair, G. (2003): Multidrug resistant Shigella dysenteriae type1 fore run-ners of anew epidemic strain in eastern India. Emerg. Infect. Dis.; 9(3): 404-405.

Welinder-Olsson, C. and KAIJSER, B. (2005): Enterohemorrhagic Escherichia coli (EHEC) Scandinavian Journal of Infectious Diseases; 37: 405_416.

Wen-jie J.;Zhi-ming Z.; Yong-zhi Z.;Ai-jian Q.; Hong-xia S.; Yuelong L.; Jiao W. and Qian-qian W. (2008): Distribution of Virulence-Associated Genes of Avian Pathogenic Escherichia coli Isolates in China. Agricultural Sciences in China, 7(12): 15111515.

Wolfgang, K.J.; Hilda, P.W.; Bernard, D.A. and Catherine, M.W. (1992): Opportunistic Enterobacteriaceae. In zinsser microbiology $20^{\text {th }}$ Edition. PrenticHall International Inc. USA, New York. 
Yaguchi, K.; Ogitani, T.; Osawa, pathogenic Escherichia coli strains R.; Kawano, M.; Kokumai, N.; isolated from chickens with Kaneshige, T.; Noro, T.; colisepticemia in Japan. Avian Dis. Masubuchi, K. and Shimizu, Y. 2007 Sep;51(3):656-62.

(2007): Virulence factors of avian

دراسات ظاهرية وجينية عن ميكروب إيشريشسا كولاى المعزول من المنتجات

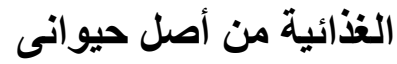

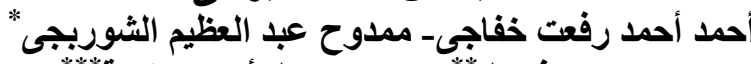

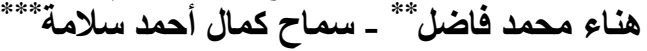

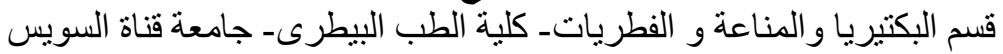

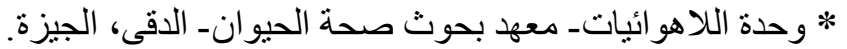

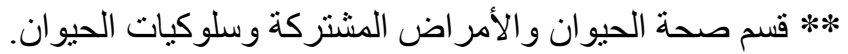

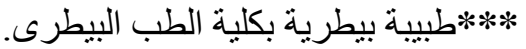

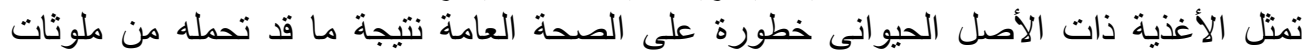

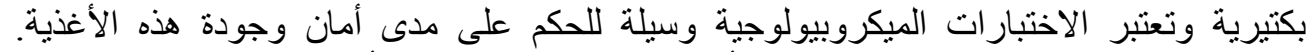

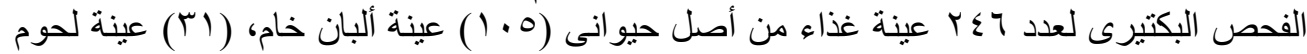

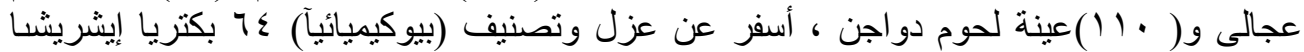

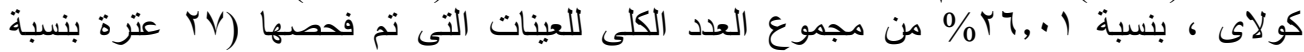

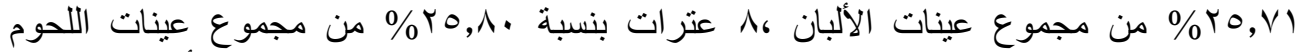

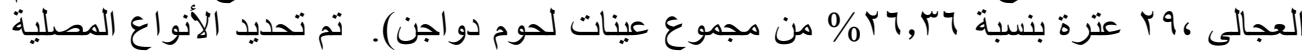

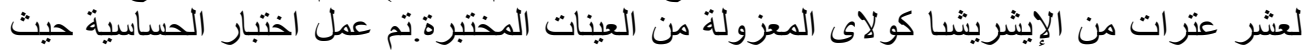

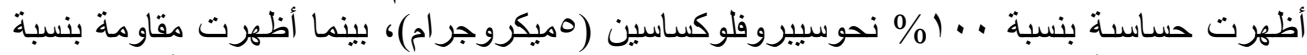

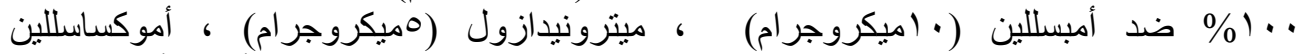

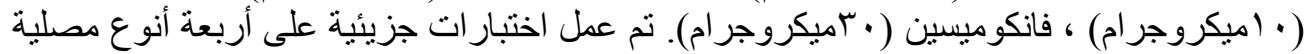

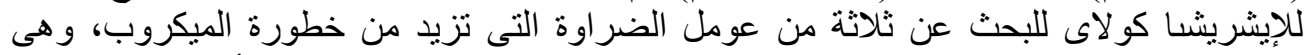

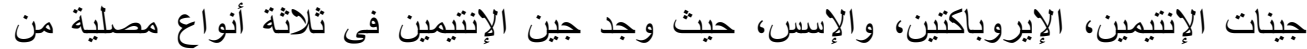
الأربعة، ووجد جين الإيروباكتين، فى الأربعة أنواع، و ووجد جين الإنس في في ثلاثة فقط منهم. 